How to cite: Adam, B.O., Nacu, S. (2020) Flood Events in Bacău County During 2005-2019. 2020 "Air and Water - Components of the Environment" Conference Proceedings, Cluj-Napoca, Romania, p. 59-70, DOI: 10.24193/AWC2020_06.

\title{
FLOOD EVENTS IN BACĂU COUNTY DURING 2005-2019
}

\author{
Bianca Otilia ADAM$M^{1}$, Simion NACU ${ }^{1}$ \\ DOI: 10.24193/AWC2020_06
}

\begin{abstract}
Flood events in Bacau county during 2005-2019. Bacău County is located on both sides of Siret River in the central part of the river basin. Bacău County has a varied and picturesque land, having the Eastern Carpathians and the hills crossed by Bistriţa, Trotuş, Siret, Tazlău, Caşin and Slănic river valleys. The first part of this article contains the most important floods that happened in Bacau county. These were recorded in the following years: 1955,1969,1970, 1975,1991, 2005, 2008 and 2010. The exceptional flood that took place from 28-29 of July, 1991 on Tazlau River, produced the failure of Belci dam: The floods produced in 1991 destroyed $47 \mathrm{~km}$ of dikes and about $117 \mathrm{~km}$ of stream gradation, flooding causing the loss of 110 human lives. The flood between 12 of July and 17 of July, 2005 was the most important due to the maximum flow rates produced (the highest during the monitoring period) and due to its catastrophic flooding effects in the Trotuş river basin. The floods produced during the period 23.07-05.08.2008 in the northern half of the Siret river basin were, in most hydrometric stations, the largest in the entire monitoring period for over 60 years. At the Drăgeşti hydrometric station was recorded a maximum historical flow of 2930 mc / s. During the period 17.06-10.07.2010, in Bacău county were several floods on the main rivers due to the abundant rainfall that fell in the area, exceeding 1001 per sqm and reaching 189.91 per sqm in Bacău, 239, 81 per sqm in Goiasa and 258, 71 per sqm in Scorțeni. During 2005-2019, a number of 23 towns were badly affected by the flood, registering over 10 events, the most affected being Moineşti with 15 events.
\end{abstract}

Keywords: torrential flow, flash-flood, effects of the flash-flood

\section{INTRODUCTION}

Bacău county is located in the central-western part of Moldova on both sides of the Siret river valley in the central part of the river basin. The surface of Bacău county is $6621 \mathrm{kmp}$, representing $2.8 \%$ of the country's surface, being the 14th county in size in Romania (Fig. 1).

The main relief units are the mountain area, the sub-Carpathians of Tazlăului, the Siret Pass and the Tutovei Hills. The mountain area occupies the western part of the county and is crossed diagonally by the Trotus river valley. On the right side are the Ciuc Mountains, the Nemira Mountains, the Oituz Mountains, and in the southwest part of the county are the Cain Mountains. On the left side of the Trotuş are the Grinduşu Mountains, Goşmani Mountains and Berzunţi Mountains.

\footnotetext{
1 "Romanian Waters" National Administration, 010018, Bucharest, Romania, E-mail: bianca.adam@rowater.rosimion.nacu@rowater.ro
} 
The sub-Carpathians of Tazlău occupy the eastern slope of the Carpathians up to the Siret's Column and include the depression of Tazlău-Caşin.

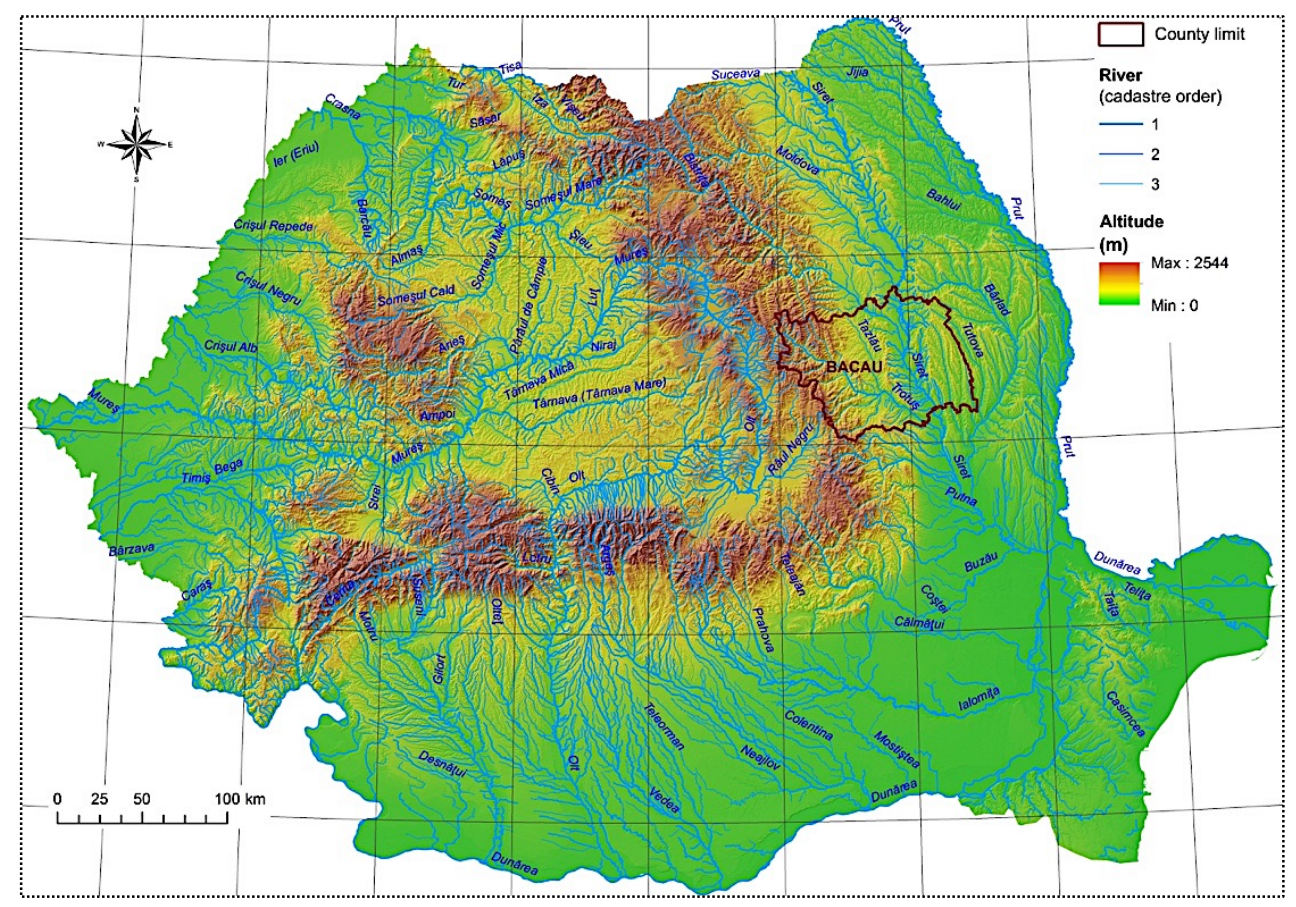

Fig. 1. Location of study area (Bacău County)

The Siret corridor is a particular unit, characterized by a large opening (15-20 $\mathrm{km}$ ), sloping mountainsides and terraces and the lower Siret and Bistrița plains.

The Tutovei hills are located in the south-eastern part of the county, to the left of Siret and represent a continuation of the Central Moldavian Plateau. They are presented in the form of relatively massive and high hills $(400-450 \mathrm{~m})$, with the maximum in Doroșanu Hill of $564 \mathrm{~m}$.

The precipitation regime is the most important element for the formation of the floods and for the side effects they induce.

The average amounts of precipitation (multiannual values) are about $5001 / \mathrm{sq} \mathrm{m}$ in the eastern part of the county, 550-600 1/ sq $\mathrm{m}$ in the Siret Pass and subCarpathian depressions (541 1/ sq $\mathrm{m}$ in Bacău, $583.51 / \mathrm{sq} \mathrm{m}$ in Tg. Ocna) and going up to $800-10001 /$ sqm (sometimes and over) on the highest mountain peaks $[1,4,5]$.

In the annual profile, the precipitation amounts are lower in the autumn-winter months (25-40 1 / sqm) and higher in the summer, in June and July (90-100 1/ sqm). For the summer period, the maximum quantities that fall in short intervals $(24 \mathrm{~h})$ are also important. Sometimes these quantities can reach and exceed $2001 / \mathrm{sq} \mathrm{m}$. This is the case of torrential rains, mainly on the day of 28/29 07/1991: 1861 / sqm in OrăşaLivezi, 1201 / sqm in Asău, 156.71 / sqm in Moineşti, 160.81 / sqm in Solonţ and Bucşeşti, 180.51 / sqm in Strugari, 140.21 / sqm in Oneşti, etc. [5]. Overall, the 
rainiest years were: 1972 (849.5 1 / mp), 1984 (769.6 1 / mp), 1991 (779.48 1/ mp), 1996 (706.2 1 / mp), rainfall recorded at the Bacău Weather Station $[4,5]$.

The hydrographic network is relatively dense and presents a differentiated flow: richer in the high mountains $(10-121 / \mathrm{sec} \mathrm{kmp})$, with a tendency of gradual decrease towards the east: 8-101/ sec / kmp on the Carpathian outskirts, 6-8 1/ sec / kmp in Subcarpathians and 4-6 1/ sec / kmp to the east of Siret $[1,5]$.

Bacău County has a varied and picturesque relief, with the Eastern Carpathians and the hills crossed by the valleys of the rivers Bistriţa, Trotuş, Siret, Tazlău, Caşin and Slănic.

The main collector is the Siret river which in Bacău county has main tributaries the Bistriţa river and the Trotuş river $[1,4,5]$.

Characteristic for all the rivers in the county is their supply, in proportion of over $70 \%$, of the water from rain and snow [1].

For all the rivers in the county the spring flow is dominant, followed by the slopes on the slopes due to the abundant rains during May-June [1, 4].

The floods are due to heavy rains, the melting of snow or the combination of the two phenomena. The most frequent floods are recorded in spring (30-50\%) and in the summer. The flash floods and the catastrophic floods, with an assurance of 0,5$1 \%$, have as main cause the great quantities of precipitations with an accentuated degree of torrentiality, which are registered after periods with the strongly moistened soil and the capacity of water absorption reduced. The accumulation lakes were set up on Siret: Galbeni, Răcăciuni and Berești. The volume of lakes exceeds $260,000,000 \mathrm{~m}^{3}$ of water (the accumulation from Galbeni $-40,000,000 \mathrm{~m}^{3}$, Răcăciuni - 104,000,000 $\mathrm{m}^{3}$ and Bereşti - 120,000,000 $\mathrm{m}^{3}$ ). [4]

The flow of the Siret river at the entrance to the county is $70 \mathrm{~m}^{3} / \mathrm{s}$, and at the exit of $137 \mathrm{~m}^{3} / \mathrm{s}$. The Bistriţa river is totally hydropower-oriented on the $42 \mathrm{~km}$ length that it crosses in Bacău county; on its course are the lakes Racova, Gârleni, Lilieci, Şerbăneşti and Bacău. On the river Uz, a tributary of the Trotus river, the Poiana Uzului dam was built.

\section{METHODOLOGY}

For the the cartographic material, topographic maps on scale 1: 25000 and Arc GIS 10.6 software licensed from the National Administration "Romanian Waters" Bucharest were used.

The study of the important floods in Bacău county was made on the basis of the specialized literature and on the basis of the data and conclusions elaborated by the specialized departments of the Siret Water Basin Administration and of the National Administration "Romanian Waters" of Bucharest.

The analysis of the risk to the floods in Bacău county was made on the basis of the data provided by the Bacau Water Management System, the Siret Water Basin Administration and the National Administration "Romanian Waters" Bucharest, for the period 2005-2019. 


\section{IMPORTANT FLOODS IN BACĂU COUNTY}

The Moldavian chronicler Grigore Ureche mentions about the floods of 1504. "Over the summer there were heavy rains and floods of water, as much as any drowning was done" [2].

The Polish historian Wapowski wrote "In the same year, which was the year of Lord 1504, in the months of March and April, the rivers swelled from the many rains and overflow out of their rivers, as had not been mentioned until then, and not long afterwards died Stefan, the palatine of Moldova, weakened by old age and pruning "[2].

Other information dated July 20,1670, belongs to the apostolic vicar Peter Parcevic, Catholic archbishop of Marcianopol who is on mission in Bacău: "As for the provinces and especially in Moldova, there is a great overflow of water for three months, due to the heavy rain showers and the constant rainfall day and night, which are destroying the sowing."[2].

In April 1706 there were floods that caused the roads to be blocked. This information was recorded by the court emissaries Mihaly Bay and Gaşpar Papay who were on mission at the royal court in Iasi.

In Moldova on June 10,1775, there is recorded "a very great drowning, as many drowning grain.... beehives... many things" [2].

In the year 1851, N. Topor quoting from the Gazeta de Moldova on June 14, "The heavy rains that follow in most days ... sometimes damages the seed ripening and the growth of the maize."

Late spring and summer of 1893 was very rainy year. In June in Bicaz, $300 \mathrm{~mm}$ were measured. There were floods on the river Bistrita.

The months of June and July 1912 were rich in rainfall, in June in Bacău there were $153 \mathrm{~mm}$. [2] Between July 6 and July 9, significant amounts of precipitation fell and floods caused great damage. The Bistrita and Siret rivers flowed affecting the cities of Piatra Neamt, Roman and Bacău.

In 1914, during the second half of the month, there were abundant rainfall in the upper basin of the Bistrita river, which exceeded $150 \mathrm{~mm}$ (Dorna $178 \mathrm{~mm}$, Fărcaşa $162 \mathrm{~mm}$, Broşteni $187 \mathrm{~mm}$ ) [2]. These precipitations produced floods on the river Bistriţa and tributaries.

In 1932 a significant flood was recorded on the river Moldova and on Siret at the Barboş hydrometric station, a maximum level of $410 \mathrm{~cm}$ was reached, $40 \mathrm{~cm}$ more than the maximum level known at that time. The highest known levels were exceeded at 70 hydrometric stations out of 229 existing ones [2].

The year 1955 was characterized by an excessively rainy time. The winter was hot and excessively rich in rainfall, the cold and very rainy spring, the cool and excessively rainy summer, and the rainy autumn. The year 1955 remains one of the rainiest years of the last 60-70 years, in the Siret basin and tributaries it was a quasi-generalized life [2].

In July 1969, on the Siret river, at the Drăgești hydrometric station, the flash flood reached the maximum flow $\mathrm{Qmax}=1900 \mathrm{~m}^{3} / \mathrm{s}$, and at the hydrometric 
station Răcătău, the maximum flow Qmax $=2220 \mathrm{~m}^{3} / \mathrm{s}$. These flows are with a probability of exceeding $5 \%$.

On the Trotus River the floods of June and July 1969, had flows with a probability of exceeding $10-20 \%$. On 8.06 .1969 on the Trotuş River at the Târgu Ocna hydrometric station, the maximum flow rate $\operatorname{Qmax}=555 \mathrm{~m}^{3} / \mathrm{s}$ was recorded, and on 12.07.1969 at the hydrometric station Vrânceni the maximum flow rate $\mathrm{Qmax}=1503 \mathrm{~m}^{3} / \mathrm{s}$ was recorded [4].

On the Tazlău river at Helegiu hydrometric station, the maximum flow velocity $\operatorname{Qmax}=521 \mathrm{~m}^{3} / \mathrm{s}$ was registered on 12.07.1969. The flows from the rivers Trotus and Tazlău had a probability of occurrence of $10-20 \%$. [4]

At the beginning of May 1970, in the very high areas of M. Rodnei, Călimani and Harghita there were still important snow reserves. The rains that fell in the first decade of May (generally 30-501 / sqm, followed by higher quantities during the period 11-14 May, caused the melting of the snow and the dangerous accumulation of the volumes of water leaked. in very well wooded areas, there have been flows that, until now, have not been matched.

The Bistriţa river basin was the most affected in the Siret hydrographic area by these floods.

On the rivers Bistriţa and Trotuş the maximum flows exceeded the highest values recorded until then [4].

During June-July 1975, due to the extraordinary precipitations that fell in the river basins of the Trotuş and Cracău rivers, very high flows were recorded. In the Trotuş river basin at the Vrânceni hydrometric station, a maximum flow rate Q $\max =2020 \mathrm{mc} / \mathrm{s}$ was recorded, flow with the probability of occurrence of $1-2 \%$.

The rainfall in the Siret river basin from June 1 to 4, 1988, generated significant increases in flows on the Trotuş and Bârlad rivers and on smaller tributaries. These flows superimposed with the high flows on the Siret river formed average floods in the Lespezi-Adjudu Vechi sector and large in the Lungoci-downstream sector [2, 5]. The maximum flow rates during the flood have a production frequency of 10-15 years on the Lower Siret (Lungoci, Şendreni) and every 5 years for the Middle Siret (Lespezi, Drăgeşti) and on the Trotuş in Vrânceni [5]

Since May 18, 1991, the Siret basin has been affected by atmospheric fronts, leading to heavy rains, which have contributed to the strong soil moistening and the surface runoff of most of the fallen rainfall. Significant floods occurred on the small tributaries of Siret, Bistrita and Trotuş.

On 3.06.1991 there was a flood in the Tazlău river basin, and on 3.07.1991 there was a flood on the tributary Şulța river of Trotuș $[5,8]$.

The most significant life of 1991 occurred at the end of July and the beginning of August this year, with the genesis in the sub-Carpathian area and with a quasigeneral evolution throughout the Siret hydrographic area.

Between May and June 1991, precipitations representing $75-125 \%$ of the multiannual average value fell [5].

On this general, wet, local background large quantities were also produced in a short time, which also produced other floods, prior to the quasi-general one from 
29.VII-3.VIII. Among them we mention those in the middle sub-basin of Tazlău (1-7.VI). There were also floods in the middle sub-basin of the river Bistriţa, downstream of Ac. Izv. Mountain.

The largest and most widespread floods occurred in the Siret hydrographic area due to the abundant rainfall that fell on July 28-29, 1991. The floods were exceptional and in many localities led to catastrophic floods with numerous human victims.and immense material damage, especially in the territory of Bacău County.

By extending the precipitation front, the duration and amounts fallen in the coming days the flood was amplified and spread on large rivers, gaining a quasigeneral character.

The precipitation quantities dropped especially during the period 28/29 July 1991 exceeded in many places 1501 / sqm in 24 hours, as follows: Orbeni 196,3 mm, Solonţ $193.6 \mathrm{~mm}$, City 186, $2 \mathrm{~mm}$, Helegiu 180, 2, Lucăceşti $160.8 \mathrm{~mm}$, Berzunţi $158.6 \mathrm{~mm}$, Moineşti 156, $7 \mathrm{~mm}$, Slobozia $155.2 \mathrm{~mm}$ and Ardeoani 152.1 $\mathrm{mm}$. (In the County Plan)

The flood on the river Tazlău of 28/29 July 1991, Belci dam, built between 1958-1962, was discharged and was a breach in the earth dam that provides closure to the left side. The breach was widened to reach about $120 \mathrm{~m}$ and through this breach and through the smaller breaches formed the complete emptying of the Belci accumulation occurred $[2,3]$.

The wine from Tazlău had a maximum flow at the Slobozia hydrometric station of $3400 \mathrm{~m}^{3} / \mathrm{s}$, the value being influenced by the breaking of the Belci dam. On the Trotus River at the Vrânceni hydrometric station there was a flow of $3750 \mathrm{~m}^{3} / \mathrm{s}$, influenced by the breaking of the Belci dam. Important floods were recorded on the small watercourses in the Siret basin: Cleja, Mocanu, Căpreanu, Răcăciuni, Solonţ, Tazlăul Sărat, Cernu, Strâmba, Valea Rea, Moreni, Helegiu. The maximum flows produced have in many cases exceeded the probability of exceeding 1\%. Apart from Belci dam has been destroyed dam on the river Mocanu Mocanu, a tributary of the river Racaciuni.

On the Cleja stream, the right tributary of Siret on 19.08 .1991 between $4.30 \mathrm{pm}$ and $5.30 \mathrm{pm}$ there was an exceptional flood with a probability of exceeding $0.1 \%$, the maximum flow rate of the flood being $290 \mathrm{~m}^{3} / \mathrm{s}$.

The breakdown of the Belci dam resulted in the immediate flooding of Slobozia. The worst is that 97 people lost their lives in these floods. 806 houses were destroyed, 4377 houses were flooded, 4603 animals died and 5732 poultry died. 69 bridges were destroyed. [5,8].

For Siret hydrographic area, the year 2005 was highlighted by the rich rains, well above the multiannual average, especially in the southern half of it. Thus, in Bacau 840.91 / sqm fell compared to the norm of 548.31 / sqm.

In the Siret hydrographic area, in 2005 there were several floods, but the most significant were during the periods July 12-17. The flood from 12-17 July 2005 was the most important due to the maximum flow rates produced (the highest during the monitoring period) and through its catastrophic flooding effects in the Trotuş river basin [5]. The precipitation that generated this flood fell during the period July 11-14, 
with maximum cores on the days of July 12-13. The quantities recorded at the rainfall stations in the most affected areas are presented in table no. $1[5,8]$.

Table 1. Precipitation quantities July 11-14, 2005

\begin{tabular}{|c|l|l|c|}
\hline $\begin{array}{c}\text { Ref. } \\
\text { no }\end{array}$ & \multicolumn{1}{|c|}{ River } & \multicolumn{1}{|c|}{$\begin{array}{c}\text { Rainfall } \\
\text { station }\end{array}$} & $\begin{array}{c}\text { Quantities } \\
\mathbf{1 1 - 1 4 . V I I ~ 1 / s q m ~}\end{array}$ \\
\hline 1 & Trotuş & Oneşti & 151,6 \\
\hline 2 & Trotuş & Vrânceni & 162,1 \\
\hline 3 & Uz & Dărmăneşti & 154,9 \\
\hline 4 & Dofteana & Dofteana & 184,5 \\
\hline 5 & Slănic & Cireşoaia & 109,6 \\
\hline 6 & Oituz & Ferăstrău & 155,6 \\
\hline 7 & Caşin & Haloş & 218,2 \\
\hline 8 & Tazlău & Tazlău & 185,3 \\
\hline 9 & Tazlău & Scorțeni & 162,4 \\
\hline 10 & Tazlău & Helegiu & 140,0 \\
\hline 11 & Tazlaul Sărat & Lucăceşti & 150,2 \\
\hline
\end{tabular}

The large amounts of precipitation, fallen in the short time, presented in the table above, generated the formation of special floods on the respective watercourses.

The most significant maximum flows are presented in table no.2. On the Siret river at the Drăgeşti hydrometric station, the vineyard did not have a significant probability, the maximum flow rate was $361 \mathrm{~m}^{3} / \mathrm{s}$, whereas on the Bistriţa river at the Frunzeni hydrometric station a maximum flow of $1205 \mathrm{~m}^{3} / \mathrm{s}$ was recorded, corresponding to a flow with a probability of exceeding $5 \%[5,8]$.

Table 2. Maximum flow rates of 2005

\begin{tabular}{|c|l|l|l|c|c|}
\hline $\begin{array}{c}\text { Ref. } \\
\text { no }\end{array}$ & River & $\begin{array}{c}\text { Hydrometrical } \\
\text { station }\end{array}$ & Qmed.VII $\left(\mathrm{m}^{3} / \mathrm{s}\right)$ & $\begin{array}{c}\text { Qmax. } \\
\text { flood } \\
\left(\mathrm{m}^{3} / \mathrm{s}\right)\end{array}$ & $\mathrm{P} \%$ \\
\hline 1 & Trotuş & Goioasa & 8,45 & 331 & 10 \\
\hline 2 & Trotuş & Tg. Ocna & 21,7 & 1490 & 0,5 \\
\hline 3 & Oituz & Ferăstrău & 3,49 & 379 & 1 \\
\hline 4 & Caşin & Haloş & 2,47 & 403 & 2 \\
\hline 5 & Trotuş & Oneşti & 30,5 & 2296 & $0,2-0,5$ \\
\hline 6 & Tazlău & Helegiu & 8,10 & 1556 & 1 \\
\hline 7 & Trotuş & Vrânceni & 41,3 & 2845 & 0,5 \\
\hline
\end{tabular}

As a result of the volume and intensity of precipitations starting with the small tributaries, there were rapid and very high increases in levels and flows with overflows, leaks from the slopes which caused large floods with propagation through tributaries (Toneni, Ursu, Corbu, Camenca, Sugura, Agas, Goioasa, Beleghet) to the river Trotuş river [5, 8]. During 12 - 14.07.2005 River Trebes was 
produced a great flood that caused flooding in the bridge area Mărgineni (DN) and neighborhoods north of the city of Bacau.

The maximum water flow recorded at the Mărgineni hydrometric station, located downstream of the mentioned bridge, was $130 \mathrm{~m}^{3} / \mathrm{s}$ and was produced on 13.07.2005, 9 o'clock.

In the section from the confluence with the Limpedea river (about $100 \mathrm{~m}$ upstream from the CFR bridge on the Bacău - Suceava line), the maximum flow produced was determined by reconstruction and had the value of $92.0 \mathrm{~m}^{3} / \mathrm{s}$.

The reconstruction of the flood was carried out in the section from the confluence with r. Limpedea, on 19.07.2005 [5].

From the research of the archival data it is found that the flood from the river Trebeş produced on 13.07.2005 is the largest of the last 25 years [5,8]. The discharged blade of water had a height of approx. $30-35 \mathrm{~cm}$ (between $\mathrm{H}$ max $164.70 \mathrm{~m}$ and the old elevation of the dam $-164.39 \mathrm{~m}$ ). The discharged flows flooded the lower lands downstream, also affected sections of S.C. International agriculture, respectively the farms near the river Bârnat and also penetrated in the northern part of Bacău municipality [5]. The floods produced during the period 23.07-05.08.2008 in the northern half of the Siret river basin were, at most hydrometric stations, the largest in the entire monitoring period for over 60 years. At the Drăgeşti hydrometric station a maximum historical flow of $2930 \mathrm{~m}^{3} / \mathrm{s}$ was recorded. This generated significant damages in Bacau county (Săuceşti commune) $[5,8]$. Hydrotechnical works were damaged, spills were created and dams were created in the Siret river. Downstream from the confluence with the Bistriţa river the flood had no negative effects, attenuating in the accumulations Galbeni, Răcăciuni, Bereşti and Călimăneşti, of a volume of about 100 mil.m³. [5]

During the period 17.06-10.07.2010, on the radius of Bacău county there were several floods on the main rivers due to the abundant rainfall that fell in the area, exceeding 1001 / sqm and reaching 189.91 / sqm in Bacău, 239, 81 / sqm in Goiasa and 258, 71 / sqm in Scorţeni.

On the night of July 27/28, 2010, in the river basin of the river Trebes and in the area of Bacau municipality, abundant rainfall fell in a short time, which generated large floods on the watercourses. In general, precipitation started after midnight.

The amounts of precipitation dropped totaled $144.31 / \mathrm{m}^{2}$ at Podiș, $110.71 / \mathrm{m}^{2}$ at Luncani, $99.31 / \mathrm{m}^{2}$ at Măgura, $92.81 / \mathrm{m}^{2}$ at Mărgineni, $1081 / \mathrm{m}^{2}$ at Bacău, etc.

It should be noted the high intensity of precipitation especially during the beginning period: Măgura $-27.51 / \mathrm{m}^{2}$ in 50 minutes (hours $1-1.50$ ), Bacău Meteo Station $-49.21 / \mathrm{m}^{2}$ in 50 minutes (hours $1.05-1.55$ ), Podiş $-104.31 / \mathrm{m}^{2}$ in 6 hours (hours 1-7) and others.

The floods that occurred as a result of these precipitations formed rapidly and had very high peaks and levels, exceeding the probabilities of exceeding $2 \%$ and even $1 \%$. $[5,8]$.

During the period 26-28.06.2010, as a result of significant amounts of precipitation, on the Trotuş river a flood formed which at the Vrânceni hydrometric station had a maximum flow of $1556 \mathrm{~m}^{3} / \mathrm{s}[5,8]$. 
The period 26.06-5.07.2010 was very rainy, especially on the days of 29.061.07.2010, when the rainfall fell shortly. Floods formed from two peaks on the rivers Bistrița and Siret. The flood on Siret River hydrometric station Balcescu had first peak at a flowrate of $1339 \mathrm{~m}^{3} / \mathrm{s}$ and the second of $1824 \mathrm{~m}^{3} / \mathrm{s}$ and hydrometric station Drăgeşti first peak had a flowrate of $2058 \mathrm{~m}^{3} / \mathrm{s}$, and the second peak has a flow value of $2884 \mathrm{~m}^{3} / \mathrm{s}$, these flows having a historical value.

Downstream of Bacău, the high flows on the Siret river, to which was added the flow of the Bistriţa river which had values up to $900 \mathrm{~m}^{3} / \mathrm{s}$, were transited through correlated maneuvers of the accumulation lakes [8].

In the period 27-28.07.2010 in the river basins of the Trebeş, Bârnat and Negel rivers, significant amounts of precipitation fell in a very short time. The fast floods formed had historical maximum flows as follows: Trebeş river at Mărgineni hydrometric station $\mathrm{Q} \max =185 \mathrm{~m}^{3} / \mathrm{s}, 2 \%$ probability; Bârnat river at the Bacău hydrometric station $\mathrm{Qmax}=167 \mathrm{~m}^{3} / \mathrm{s}$, probability of 2-5\%; Negel river at Măgura hydrometric station, $\operatorname{Qmax}=96.7 \mathrm{~m}^{3} / \mathrm{s}$, probability $0.2-0.5 \%$ [4.8].

During the period 12-13.10.2016, important quantities of precipitation fell on the Bacău County area. On the Trotus river an important flood was formed, with a maximum flow of $2750 \mathrm{~m}^{3} / \mathrm{s}$, for whose transit the accumulations on Siret downstream of Adjud, and the accumulations on the Bistriţa river and the accumulations of Galbeni, Răcăciuni and Berești on the Siret river, reduced the machined flows to 0 and accumulated the affluent flows $100 \%$ [8].

\section{RESULTS AND DISSCUSIONS}

During the period studied, the years 2005-2019, in Bacău county were important floods on the Siret, Bistriţa, Trotuş rivers and their tributaries in 2005, 2008, 2010 and 2016.

The flood from 12-17 July 2005 was the most important due to the maximum flow rates produced (the highest during the monitoring period) and through its catastrophic flooding effects in the Trotuş river basin.

In this study it was counted how many years a locality was affected by floods. The results are presented on the map of Bacău county (Fig. 2).

The town of Helegiu has been affected by floods in 11 years, from the studied period. The localities of Berești-Tazlău, Corbasca, Dealu Morii, Margineni, Moineşti and Solonţ were affected by floods in 10 years, from the studied period.

The localities of Bârsăneşti, Brusturoasa, Comăneşti, Poduri, Strugari and Târgu Ocna were affected in 9 years.

The localities of Odobeşti, Onceşti and Secuieni, were the least affected by the floods. In these localities only in two years floods were recorded. The localities of Bereşti-Bistriţa, Coţofăneşti, Izvorul Beherciului, Stănişeşti and Vultureşti were affected only in three years by floods.

For the period 2005-2019, the number of events, ie how many events generated by the floods, were recorded for each locality. 


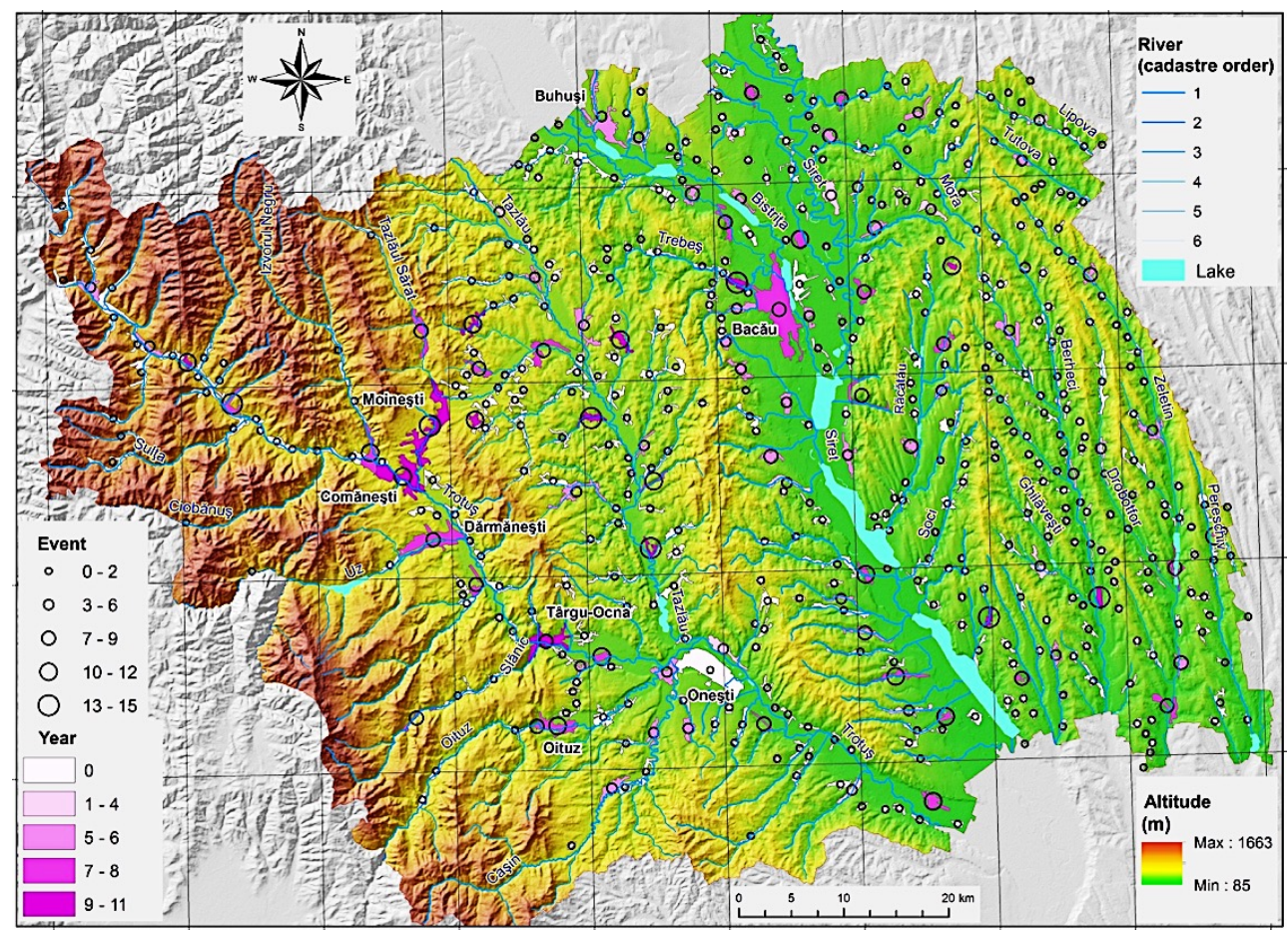

Fig. 2 The situation with the number of years in which the localities were affected by the floods

The results are shown on the map of Bacău county (fig. 3). A total of 26 localities out of a total of 93 were affected at least 10 times by floods. The most affected were Moinești, Dealu Morii and Mărgineni localities which was affected by 15 floods. Helegiu were affected by 14 flood events. Agaş, Bereşti-Tazlău, Brusturoasa and Corbasca were affected by 13 flood events. Săucești locality was affected by 12 events, and the localities Asău, Blăgeşti, Oituz, Poduri, Răcăciuni, Solonţ, Strugari, Târgu Trotuş and Urechești were affected 11 times by floods. The localities of Bârsăneşti, Comăneşti, Damieneşti, Dofteana, Hemeiuş, Livezi, Oituz, Sascut and Valea Seacă were affected 10 times.

The localities least affected by the floods are Odobeşti and Onceşti with 2 events, and the localities Bereşti-Bistriţa, Coţofăneşti, Izvorul Beherciului, Secuieni, Stănişeşti and Vultureni were affected by 3 flood events.

It is noted that the most affected by the floods are the localities in the river basin of the Trotus River. A total of 60 localities had between 4 and 9 flood events, between 2005-2019.

\section{CONCLUSIONS}

The localities least affected by the floods are Bereşti-Bistriţa, Odobeşti and Onceşti with 2 events. The localities of Coţofăneşti, Izvorul Beherciului, Secuieni, Stănişeşti and Vultureni were affected by 3 floods. 


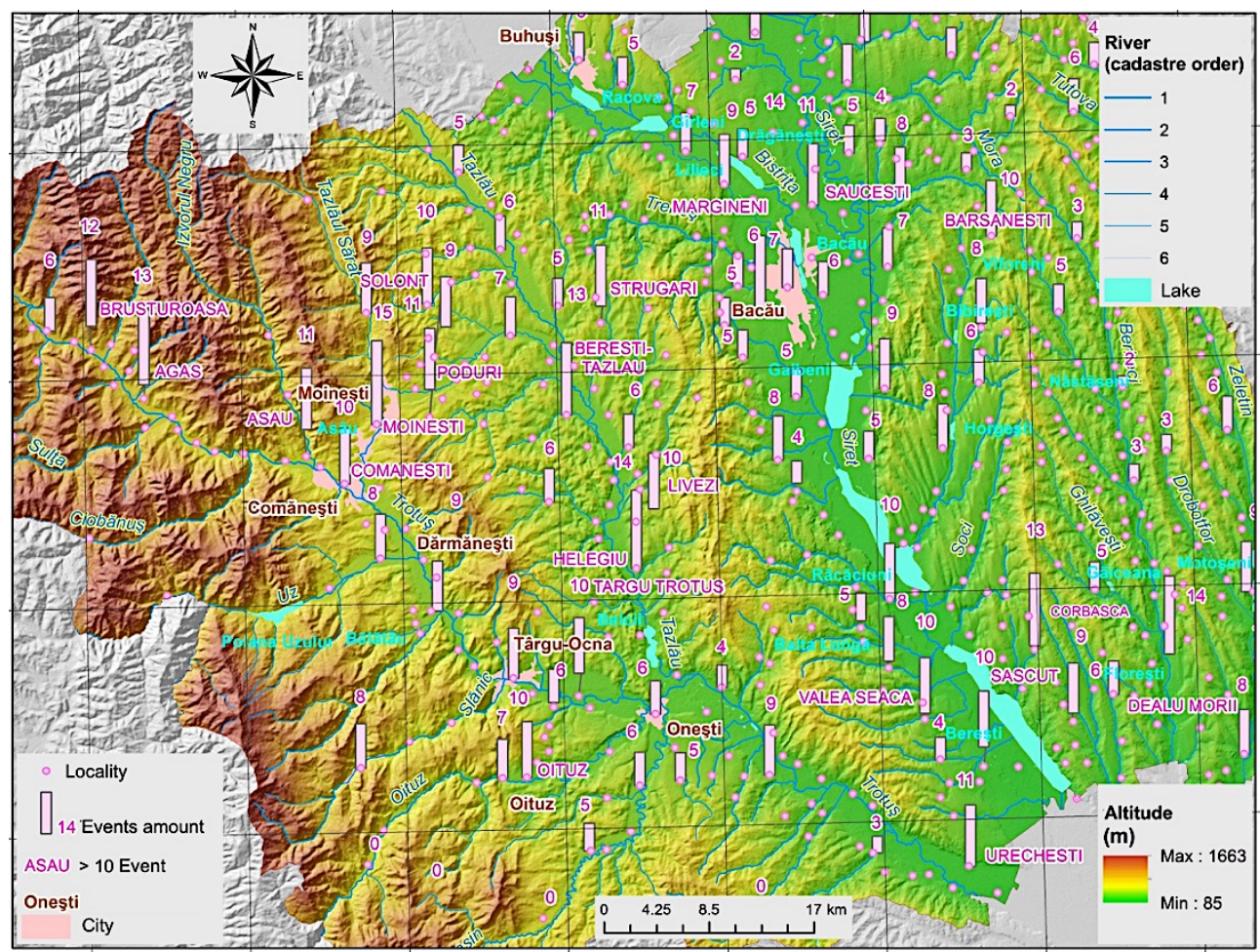

Fig. 3. Flood events in Bacău county

The most affected by the flood localities in Bacău county are: Moineşti, Dealul Morii and Mărgineni with 15 events, Helegiu, with 14 events, Agaş, BereştiTazlău, Brusturoasa, Corbasca with 13 events and Săucești with 12 events.

Helegiu was affected by floods in 11 years, recording 14 events.

In the period 2005-2019, in Bacău County there were historical floods on the Siret, Bistrita, Trotus and tributary rivers.

The years with the highest losses and damages were 2005, 2008, and 2010.

The flood from July 12-17, 2005 was the most important due to the maximum flow rates produced (the highest during the monitoring period) and through its catastrophic flood effects in the Trotuş river basin.

The flash floods occurred between 23.07-05.08.2008 in the northern half of the basin of Siret River were, for many hydrometric stations, the largest in the entire monitoring period of 60 years. At the Drăgeşti hydrometric station, a historical maximum flow of $2930 \mathrm{~m}^{3} / \mathrm{s}$ was recorded.

The period 26.06-5.07.2010 was very rainy, especially on the days of 29.061.07.2010, when the rainfall fell shortly. Floods formed from two peaks on the rivers Bistriţa and Siret. The flood on the Siret river at the Nicolaie Bălcescu hydrometric station had the first peak at a flow value of $1339 \mathrm{~m}^{3} / \mathrm{s}$ and the second one at $1824 \mathrm{~m}^{3} / \mathrm{s}$, and at the Drăgeşti hydrometric station, the first peak had a flow 
value of $2058 \mathrm{~m}^{3} / \mathrm{s}$, and the second peak has a flow value of $2884 \mathrm{~m}^{3} / \mathrm{s}$, these flows having a historical value.

In the period 27-28.07.2010 in the river basins of the Trebeş, Bârnat and Negel rivers, significant amounts of precipitation fell in a very short time. The fast floods formed had historical maximum flows as follows: Trebeş river at Mărgineni hydrometric station Q $\max =185 \mathrm{~m}^{3} / \mathrm{s}, 2 \%$ probability; Bârnat river at the Bacău hydrometric station $\mathrm{Qmax}=167 \mathrm{~m}^{3} / \mathrm{s}$, probability of 2-5\%; Negel river at Măgura hydrometric station, $\operatorname{Qmax}=96.7 \mathrm{~m}^{3} / \mathrm{s}$, probability $0.2-0.5 \%$.

During the period 12-13.10.2016, important quantities of precipitation fell on the Bacău County area. On the Trotus river an important flood was formed, with a maximum flow of $2750 \mathrm{~m}^{3} / \mathrm{s}$, for whose transit the accumulations on Siret downstream of Adjud, and the accumulations on the Bistriţa river and the accumulations of Galbeni, Răcăciuni and Bereşti on the Siret river, have reduced flow rates at 0 and accumulated machined tributary flows $100 \%$.

Floods on the river Siret and Bistrita can be controlled by reservoirs, instead of the river Trotus can't be controlled. To reduce the risk of flooding on the Trotus River, it is necessary to restore the Belci dam, destroyed by the 1991 flood.

\section{REFERENCES}

1. Lupu, N.N, Văcăraşu, I., Brânduş, C. (1972) Judeţul Bacău. Editura Academiei R.S.R., București.

2. Mustăţea A., (2005), Viituri excepţionale pe teritoriul României, Editura INHGA, Bucureşti

3. Stematiu D.,(2018), Accidente şi incidente la construcţii hidrotehnice-Relatări din experienţa proprie, Editura AGIR, Bucureşti

4. *** (2017), Planul de analiză şi acoperirea riscurilor de pe teritoriul judeţului Bacău, Consiliul Județean Bacău Bacău, http://www.isubacau.ro/materiale/cjsu/PAAR2015.pdf

5. *** (2018), Planul judeţean de apărare împotriva inundaţiilor, fenomenelor meteorologice periculoase, accidentelor la construcţii hidrotehnice şi poluărilor accidentale al județului Bacău, Sistemul de Gospodărire al Apelor Bacău, Bacău

6. Diaconu, C., (1971) Rîurile României-monografie hidrologică, Institutul de Meteorologie şi Hidrologie, Bucureşti;

7. ***, (1992), Atlasul cadastrului apelor din România, Ministerul Mediului, Bucureşti.

8. $* * *$ http://www.anar.ro/Lists/Sinteza 